Article

\title{
The Simultaneous Removal of Zinc and Cadmium from Multicomponent Aqueous Solutions by Their Sorption onto Selected Natural and Synthetic Zeolites
}

\author{
Bożena Kozera-Sucharda ${ }^{1}$, Barbara Gworek ${ }^{2}$ and Igor Kondzielski ${ }^{2, *(1)}$ \\ 1 Department of Soil Science, Warsaw University of Life Sciences, Nowoursynowska str. 159, 02-776 Warsaw, \\ Poland; bi@ios.edu.pl \\ 2 Institute of Environmental Protection-National Research Institute, Krucza 5/11D str., 00-548 Warsaw, Poland; \\ barbara.gworek@ios.edu.pl \\ * Correspondence: igor.kondzielski@ios.edu.pl; Tel.: +48-22-375-05-78; Fax: +48-22-375-05-01
}

Received: 2 March 2020; Accepted: 9 April 2020; Published: 11 April 2020

\begin{abstract}
Natural and synthetic aluminosilicate minerals, in particular zeolites, are considered to be very useful in remediation processes, such as purification of waters polluted with heavy metals. That is due to their unique and outstanding physico-chemical properties, rendering them highly efficient, low-cost, and environmentally friendly sorbents of various environmental pollutants. The aim of this study was to examine the sorption capacity of four selected zeolites: A natural zeolite and three synthetic zeolites (3A, 10A, and 13X), towards zinc and cadmium present in multicomponent aqueous solutions, in relation to identified sorption mechanisms. It was stated that synthetic zeolites $3 \mathrm{~A}$ and 10A were the most efficient in simultaneous removal of zinc and cadmium from aqueous solutions. Additionally, zeolite $10 \mathrm{~A}$ was demonstrated to be the mineral best coping with prolonged pollution of water with those elements. The mechanism of sorption identified for tested minerals was physisorption.
\end{abstract}

Keywords: water; zinc; cadmium natural and synthetic zeolites

\section{Introduction}

The observed, in the last two centuries, rapid technological development, pronouncing itself in growing industrialization and urbanization, resulted in the rapid increase of pollution of the environment with various chemicals, including trace elements such as heavy metals. Their ongoing accumulation in various environmental compartments, resulting from a systematic deposition, is now considered to be a permanent phenomenon. From that arises a severe danger and an onerous problem to all environmental compartments, including, in the aquatic compartment, that of the permanent pollution, resulting in the inclusion of the toxic elements to the food chains, impacting the proper functioning of the ecosystems and putting into high risk human health [1-4]. For that reason, the concentrations of many of those pollutants, including heavy metals, are continuously monitored by relevant national and international organizations. In those activities special consideration is given to water, one of the most important renewable resources of the Earth. Water is one of the most precious and most commonly used renewable resources. Abundant in the Earth's crust, it covers two thirds of the planet's surface [5]. However, only $0.3-0.5 \%$ of that amount is fresh water accessible to human beings, and that volume diminishes due to pollution from various point and spatial sources. Therefore, so important becomes the issue of water protection by reducing the emissions from identified and potential sources and remediation of polluted surface and ground water using different, efficient techniques. 
Heavy metals are listed among the most important environmental pollutants, due to their chemical nature. As chemical elements they are not prone to degradation in the environment, only to change of the form of their occurrence. As a result, they tend to accumulate in various environmental compartments thus becoming permanent pollutants. They enter the environment as a result of various human activities, metallurgy, chemical, and electro-technical and engineering industries, but also agriculture. Among most important of their point sources are listed various untreated industrial effluents as well as the accidental emissions from industrial and municipal wastewater treatment installations and dumping sites. Major spatial sources are indicated as agricultural and municipal effluents as well as dry and wet atmospheric deposition.

Zinc and cadmium are two heavy metals ranked highly among the environmental pollutants, due to their wide abundance and toxicity [6]. Belonging to the same group in the periodic table, IIb, those two elements have similar properties and, hence, display very similar behavior in the environment, for instance, in soil [7-9]. Lighter zinc, although an important microelement of well examined roles in living organisms [10], in elevated concentrations is known to adversely affect living organisms. Heavier cadmium has no known biological role, but well demonstrated high toxicity to all living organisms already in low concentrations. Both elements display a tendency to accumulate in living organisms and ecosystems, as well as a long residence time (in the case of cadmium, estimated at 10 to 33 years), which causes severe health problems. For that reason, so important becomes removing those compounds from various environmental matrices, in particular water, the medium in which they are most readily bioavailable.

The possibilities of the efficient removal of heavy metals from polluted waters and of the limiting of the inclusion of heavy metals to the food chain at the level of plants-soils interactions was the subject of numerous studies, also performed by the authors of this work [11-24]. Those findings were at the basis of the experimental hypothesis of this research, which assumed that natural and synthetic aluminosilicate minerals were highly efficient, low-cost, and environmentally friendly materials in removal of heavy metals from water. The possibility of removal of heavy metals from aqueous solution by means of their sorption onto various materials, including mineral sorbents, was extensively examined [22,25,26], but most of those research activities concentrated on single-solute systems. It was also demonstrated that the sorption of metal ions from aqueous multisolute systems onto various sorbents may result in different sorption parameters than those obtained for the same chemicals in single-solute systems [27-29].

The main aim of the study was the assessment of the possibility of use of selected porous aluminosilicate minerals having a network of pores and chambers, zeolites, to decontaminate water containing elevated levels of zinc and cadmium, as observed in the case of accidental emissions in highly concentrated effluents bearing various metal ions. This was done with the aim to provide a deeper insight into the problem of simultaneous sorption of metal elements with almost identical chemical behavior from binary system onto sorbents belonging to the same class but varying in sorptive capacities. Also, the results should provide a clear indication for practitioners on which sorbent to use in case of accidental high-concentration releases of zinc and cadmium to the aquatic environment, hitherto seldom done in scientific papers.

To achieve that, four selected zeolites, one natural and three synthetic, were examined for their sorption capacity and selectivity towards zinc and cadmium ions present in multicomponent aqueous solutions. An attempt was also made to identify the possible mechanisms of sorption of $\mathrm{Zn}^{2+}$ and $\mathrm{Cd}^{2+}$ by the tested minerals. To obtain a clear and unambiguous answer to the question of the efficiency of each tested mineral in removal of the elements of concern from remediated water, the concentration of the test metals in the study were correlated with the cation exchange capacity (CEC) factor of the minerals undergoing examination. 


\section{Materials and Methods}

In this study we used four porous aluminosilicate minerals-zeolites. They were crystalline hydrated minerals displaying high variability of internal structure, containing characteristic empty spaces, channels and chambers, filled with ions and water molecules having a high degree of freedom of movement.

Chemically, zeolites are hydrated aluminosilicates of metals belonging to Ia ( $\mathrm{Li}, \mathrm{Na}, \mathrm{K}$ ) and IIa $(\mathrm{Mg}, \mathrm{Ca}, \mathrm{Sr}, \mathrm{Ba})$ groups of the periodic table, which compensate the negative charge. The simplified chemical formula of any zeolite can be presented as follows:

$$
\mathrm{Me}_{2 / \mathrm{n}} \mathrm{O} \cdot \mathrm{Al}_{2} \mathrm{O}_{3} \cdot x \mathrm{SiO}_{2} \cdot \mathrm{yH} \mathrm{H}_{2} \mathrm{O}
$$

where Me is metal cation, $\mathrm{n}$ is valency of the metal cation, and $\mathrm{x}$ is molar ratio $\mathrm{SiO}_{2} / \mathrm{Al}_{2} \mathrm{O}_{3}$.

From the structural point of view, the basic elements of their crystalline network are tetrahedras $\left[\mathrm{SiO}_{4}\right]^{2-}$ and $\left[\mathrm{AlO}_{4}\right]^{-}$linked by the oxygen bridges to form the polyhedras, e.g., cuboctahedras. The spatial arrangements of cuboctahedras and their binding structures result in different structural types of zeolites, e.g., A, X and Y, all belonging to the faujasite group.

Zeolites are also called molecular sieves, because of their ability of selective sorption of chemical molecules that are smaller than their sorption holes.

In this study we used the natural zeolite, clinoptilolite, obtained from Caucasian deposits, and three synthetic zeolites, 3A, 10A, and 13X.

The natural zeolite, clinoptilolite, has dominant exchangeable cations $\mathrm{K}^{+}$and $\mathrm{Ca}^{2+}$ and the pores' diameter of $0.44-0.55 \mathrm{~nm}$. To obtain higher homogeneity it was ground to obtain the grain size of $<0.2 \mathrm{~mm}$.

Of the three synthetic zeolites, two are the representatives of type A and the third is an X-type zeolite. Their exemplary structural models are presented below in Figure 1.

Structural Model of A-Type Zeolite

A cubeoctahedr
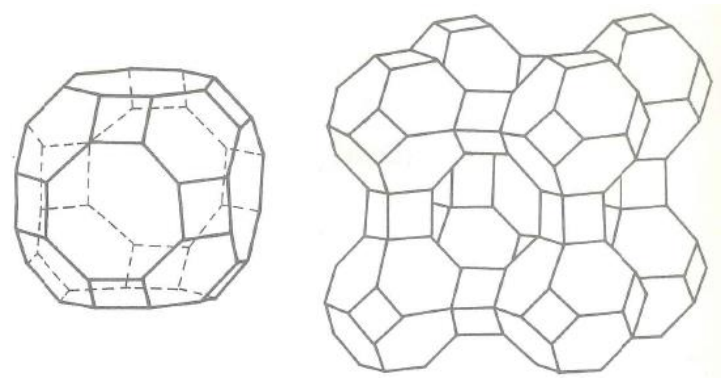

\section{Structural Model of X-Type Zeolite}

A cubeoctahedr

A single crystal
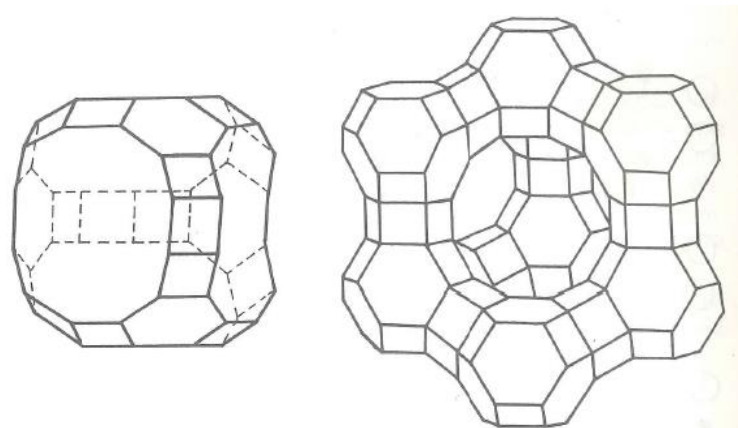

Figure 1. Exemplary structural modes of A-type and X-type synthetic zeolites used in the study.

The tested synthetic zeolite $3 \mathrm{~A}$ is a sodium-and-potassium zeolite with pores' diameter of $0.38 \mathrm{~nm}$, zeolite 10A is a sodium zeolite with pores' diameter of $0.9-1.0 \mathrm{~nm}$, and zeolite 13X is a sodium zeolite with pores' diameter of $0.9-1.0 \mathrm{~nm}$.

The basic properties of all characterized above aluminosilicate minerals are presented below in the Table 1. 
Table 1. The basic properties of each of the minerals used in the experiment.

\begin{tabular}{|c|c|c|c|c|c|}
\hline \multirow{3}{*}{\multicolumn{2}{|c|}{ Property }} & \multicolumn{4}{|c|}{ Minerals } \\
\hline & & \multirow{2}{*}{ Natural Zeolite } & \multicolumn{3}{|c|}{ Synthetic Zeolites } \\
\hline & & & $3 \mathrm{~A}$ & $10 \mathrm{~A}$ & $13 X$ \\
\hline \multicolumn{2}{|c|}{ Grain size [mm] } & $<0.2$ & 1.0 & 1.0 & 1.0 \\
\hline \multirow{2}{*}{$\mathrm{pH}$} & in $\mathrm{H}_{2} \mathrm{O}$ & 6.1 & 0.2 & 9.4 & 10.1 \\
\hline & in $1 \mathrm{M} \mathrm{KCl}$ & 4.7 & 8.8 & 7.9 & 8.9 \\
\hline \multirow{6}{*}{$\begin{array}{c}\text { Content of } \\
\text { exchangeable } \\
\text { cations }[\mathrm{cmol} / \mathrm{kg}]\end{array}$} & Total-CEC & 93.9 & 354.1 & 377.9 & 235.2 \\
\hline & $\mathrm{Na}^{+}$ & 1.7 & 146.5 & 364.2 & 223.7 \\
\hline & $\mathrm{K}^{+}$ & 46.1 & 200.3 & 8.4 & 3.8 \\
\hline & $\mathrm{Mg}^{2+}$ & 1.5 & 0.5 & 2.4 & 1.5 \\
\hline & $\mathrm{Ca}^{2+}$ & 44.6 & 6.8 & 2.9 & 6.2 \\
\hline & Dominant cations & $\mathrm{K}^{+}$and $\mathrm{Ca}^{2+}$ & $\mathrm{K}^{+}$and $\mathrm{Na}^{+}$ & $\mathrm{Na}^{+}$ & $\mathrm{Na}^{+}$ \\
\hline
\end{tabular}

CEC, cation exchange capacity.

The examination of the sorption of zinc and cadmium onto four tested minerals was performed using multisolute aqueous solutions containing $\mathrm{Zn}^{2+}$ and $\mathrm{Cd}^{2+}$, in initial concentrations corresponding to $2 \%$ CEC, $10 \%$ CEC, $20 \%$ CEC, $30 \%$ CEC, 50\% CEC, $75 \%$ CEC, and 100\% CEC (cation exchange capacity) of the given mineral sorbent. Those solutions were prepared from the stock solutions using the serial dilution method.

Stock solutions were prepared individually for each tested mineral by dissolving the appropriate samples of solid nitrate salts of the test elements (analytical grade) in deionized water to obtain the mixture having the total concentration of test ions equal to $100 \%$ CEC of the given mineral sorbent.

The experiment was performed to comply with the methodology outlined in the OECD Guideline 106 [30]. It consisted of two stages, initial, at which were determined the adequate equilibration time and the incubation temperature, and the definitive stage, aimed at the determination of the sorption capacity of each tested mineral towards each of the test metal ions.

The whole experiment was performed using a constant, predefined mineral sorbent with solution ratio of 1:25. For the definitive test, aimed at the determination of the sorption capacity of each mineral towards each cation, seven polymetallic solutions were prepared. The experiment was performed in a batch mode. All samples were equilibrated by shaking at constant speed on a horizontal shaker placed in a water bath set to the constant temperature. After equilibration, the samples were centrifuged, clarified supernatants decanted, and the content of metal ions in them determined by AAS to obtain the equilibrium concentrations in solution- $\mathrm{C}_{\mathrm{e}}$.

The equilibrium concentrations of each metal adsorbed onto sorbent were calculated from a difference between the initial concentration in the solution and that determined experimentally after equilibration.

Each sample was prepared in four replicates.

For each mineral and each initial concentration, we determined the percent sorption and the distribution coefficient, $\mathrm{K}_{\mathrm{d}}$.

Those two parameters were calculated using the following equations.

1. For the determination of the $\%$ of sorption:

$$
\% \text { sorption }=\left[\left(\mathrm{C}_{\mathrm{INI}}-\mathrm{C}_{\mathrm{e}}\right) / \mathrm{C}_{\mathrm{INI}}\right] \times 100
$$

where $C_{\text {INI }}$ is the initial concentration of the given metal ion in the test solution in [cmol/L] $\mathrm{C}_{\mathrm{e}}$-concentration of the given metal ion in the solution at equilibrium in $[\mathrm{cmol} / \mathrm{L}]$.

2. For the determination of the distribution constant $\mathrm{K}_{\mathrm{d}}$ :

$$
\mathrm{K}_{\mathrm{d}}=\mathrm{C}_{\mathrm{sorb}} / \mathrm{C}_{\mathrm{e}}[\mathrm{L} / \mathrm{kg}]
$$


where $C_{e}$ is the concentration of the given metal ion in the solution at equilibrium in $[\mathrm{cmol} / \mathrm{L}]$ and $\mathrm{C}_{\text {sorb }}$ is the concentration of the given metal ion adsorbed onto the mineral sorbent at equilibrium in $[\mathrm{cmol} / \mathrm{kg}]$.

The data obtained for each mineral were also analyzed with the aim to determine the parameters of the sorption isotherms, characterizing sorption capacity, and the mechanisms of the process. Three isotherm models were used: Freundlich isotherm, Langmuir isotherm, and Dubinin-Kaganer-Radushkevich (DKR) isotherm. All three isotherms are commonly used to characterize the process of monolayer sorption from solutions onto heterogeneous surfaces.

Freundlich and Langmuir adsorption isotherms are the general purpose isotherms, used to characterize the monolayer sorption of various chemicals, including heavy metals, from aqueous solutions onto heterogeneous sorbent systems, such as minerals [31]. Both isotherms, extensively characterized in many publications [32-37], are single-solute models, but easily adaptable to examine sorption of various chemicals, including metal ions, in multisolute systems [38-43].

In their canonical forms they are represented by the following equations. Freundlich isotherm:

$$
\mathrm{x} / \mathrm{m}=\mathrm{K}_{\mathrm{f}} \times \mathrm{Cs}^{1 / \mathrm{n}}
$$

where $x / m$ is the amount of the sorbate sorbed at equilibrium, $C_{s}$ is the concentration of the sorbate in solution at equilibrium, $K_{\mathrm{f}}$ is the Freundlich isotherm sorption constant, and $1 / n$ is the Freundlich sorption coefficient. Langmuir isotherm:

$$
\mathrm{x} / \mathrm{m}=\left(\mathrm{K}_{\mathrm{L}} \times \mathrm{N}_{\mathrm{S}} \times \mathrm{C}_{\mathrm{S}}\right) /\left(1+\mathrm{K}_{\mathrm{L}} \times \mathrm{C}_{\mathrm{S}}\right)
$$

where $x / m$ is the amount of the sorbate sorbed at equilibrium, $C_{s}$ is the concentration of the sorbate in solution at equilibrium, $\mathrm{K}_{\mathrm{L}}$ is Langmuir's isotherm sorption constant, and $\mathrm{N}_{\mathrm{s}}$ is the number of sorption sites (also named "maximum adsorption capacity").

Although, for convenience, they are usually used in their linearized form, as logarithmically transformed equations, for the purpose of this work the data were fitted to the presented above canonical forms. That is due to several limitations of the linear regression methods in comparison to the nonlinear regression ones [44-48].

The third isotherm used in the study, the DKR (Dubinin-Kaganer-Radushkevich) isotherm, is a model characterizing the adsorption onto micropores [49,50]. It is used to determine two important parameters, the maximum sorption capacity of the tested sorbent towards the given adsorbate $\left(X_{m}\right)$ and the mean adsorption free energy $\mathrm{E}$, an indicator of the mechanism of the examined process [51-54]. Although generally applicable to single-solute systems, that model was demonstrated to be successful in the characterization of sorption in multicomponent systems [55].

Being in its canonical form the exponential equation [56-58], for convenience it is commonly used in linearized form (after [59]):

$$
\ln C_{\text {ads }}=\ln X_{m}-\beta \varepsilon^{2}
$$

where $C_{a d s}$ is the amount of metal ions adsorbed per unit weight of sorbent (here in $[\mathrm{cmol} / \mathrm{kg}]$ ), $X_{m}$ is the maximum sorption capacity, $\beta$ is the activity coefficient related to mean sorption energy, and $\varepsilon$ is the Polanyi potential.

Polanyi potential is expressed using the following equation:

$$
\varepsilon=\mathrm{RT} \times \ln \left(1+1 / \mathrm{C}_{\mathrm{e}}\right)
$$

where $C_{e}$ is the amount of metal ions remaining in solution at equilibrium (here in $\left[\mathrm{cmol} / \mathrm{dm}^{3}\right]$ ), $R$ is the gas constant (in $\left[\mathrm{kJ} \mathrm{mol}^{-1} \mathrm{~K}^{-1}\right]$ ), and $\mathrm{T}$ is the temperature in $[\mathrm{K}]$. 
The value of the energy is used as the indicator of the mechanism of the process, physisorption, ion exchange, or chemisorption $[37,60,61]$. It is calculated from the activity coefficient using the following equation:

$$
\mathrm{E}=1 / \sqrt{ }(-2 \beta)
$$

All three sorption isotherm models used in this study were determined using the tool CurveExpert Professional ver. 2.6.5. In the case of Freundlich's and Langmuir's isotherms, the nonlinear regression method was used, while the linearized DKR isotherm was optimized using the linear regression. For Freundlich's isotherm, the built-in tool, "Power" function, was used, Langmuir's isotherm was optimized using the user's model, and for the DKR isotherm we used the model built-in linear function.

\section{Results and Their Discussion}

The preliminary experiment showed that the equilibrium state was reached after $1 \mathrm{~h}$. That time was, therefore, selected as equilibration time in further experiments.

The examination of the influence of the temperature on the sorption showed that the optimum sorption was attained at $\mathrm{T}=20^{\circ} \mathrm{C}$. Therefore, for the definitive experiment, that temperature was selected, as it was considered to be representative for the average environmental conditions.

For each tested combination $\mathrm{Me}^{2+}$-mineral sorbent and each tested concentration, we calculated the percentage of sorption and the values of the distribution coefficient $\mathrm{K}_{\mathrm{d}}$. The results are presented numerically in the Table 2.

Table 2. The results of the examination of sorption of $\mathrm{Zn}^{2+}$ and $\mathrm{Cd}^{2+}$ onto tested zeolites, \% sorption, and $K_{d}$ values.

\begin{tabular}{|c|c|c|c|c|c|c|c|}
\hline \multicolumn{8}{|c|}{ Sorbent: Natural Zeolite } \\
\hline \multicolumn{4}{|c|}{ Sorbed Element: $\mathrm{Zn}^{2+}$} & \multicolumn{4}{|c|}{ Sorbed Element: $\mathrm{Cd}^{2+}$} \\
\hline \multicolumn{2}{|c|}{$\begin{array}{l}\text { Initial Concentration of } \mathrm{Zn}^{2+} \\
\text { in Solution Expressed: }\end{array}$} & \multirow{2}{*}{$\begin{array}{c}\% \\
\text { Sorption }\end{array}$} & \multirow{2}{*}{$\underset{[L / k g]}{K_{d}}$} & \multicolumn{2}{|c|}{$\begin{array}{l}\text { Initial Concentration of } \mathrm{Cd}^{2+} \\
\text { in Solution Expressed: }\end{array}$} & \multirow{2}{*}{$\begin{array}{c}\% \\
\text { Sorption }\end{array}$} & \multirow{2}{*}{$\begin{array}{c}\mathrm{K}_{\mathrm{d}} \\
{[\mathrm{L} / \mathbf{k g}]}\end{array}$} \\
\hline in $[\mathrm{cmol} / \mathrm{L}]$ & as \% CEC & & & in $[\mathrm{cmol} / \mathrm{L}]$ & as \% CEC & & \\
\hline 0.02 & 2 & 50.00 & 25.00 & 0.02 & 2 & 100.00 & n. c. ${ }^{*}$ \\
\hline 0.10 & 10 & 60.00 & 37.50 & 0.10 & 10 & 50.00 & 25.00 \\
\hline 0.20 & 20 & 54.50 & 20.45 & 0.20 & 20 & 35.00 & 13.46 \\
\hline 0.30 & 30 & 43.33 & 19.12 & 0.30 & 30 & 30.00 & 10.71 \\
\hline 0.50 & 50 & 34.00 & 12.88 & 0.50 & 50 & 20.00 & 6.25 \\
\hline 0.70 & 75 & 31.43 & 11.46 & 0.70 & 75 & 18.57 & 5.70 \\
\hline 0.99 & 100 & 29.29 & 10.36 & 1.00 & 100 & 16.00 & 4.76 \\
\hline \multicolumn{8}{|c|}{ Sorbent: Zeolite 3A } \\
\hline \multicolumn{4}{|c|}{ Sorbed Element: $\mathrm{Zn}^{2+}$} & \multicolumn{4}{|c|}{ Sorbed Element: $\mathrm{Cd}^{2+}$} \\
\hline \multicolumn{2}{|c|}{$\begin{array}{l}\text { Initial Concentration of } \mathrm{Zn}^{2+} \\
\text { in Solution Expressed: }\end{array}$} & \multirow[t]{2}{*}{$\begin{array}{c}\% \\
\text { Sorption }\end{array}$} & \multirow[t]{2}{*}{$\begin{array}{c}\mathrm{K}_{\mathbf{d}} \\
{[\mathrm{L} / \mathrm{kg}]}\end{array}$} & \multicolumn{2}{|c|}{$\begin{array}{l}\text { Initial Concentration of } \mathrm{Cd}^{2+} \\
\text { in Solution Expressed: }\end{array}$} & \multirow[t]{2}{*}{$\begin{array}{c}\% \\
\text { Sorption }\end{array}$} & \multirow[t]{2}{*}{$\begin{array}{c}\mathrm{K}_{\mathrm{d}} \\
{[\mathrm{L} / \mathrm{kg}]}\end{array}$} \\
\hline in $[\mathrm{cmol} / \mathrm{L}]$ & as \% CEC & & & in $[\mathrm{cmol} / \mathrm{L}]$ & as $\%$ CEC & & \\
\hline 0.07 & 2 & 57.14 & 33.33 & 0.07 & 2 & 57.14 & 33.33 \\
\hline 0.37 & 10 & 40.54 & 17.04 & 0.36 & 10 & 41.67 & 17.86 \\
\hline 0.74 & 20 & 64.86 & 46.51 & 0.73 & 20 & 52.05 & 27.14 \\
\hline 1.10 & 30 & 60.00 & 37.50 & 1.09 & 30 & 49.54 & 24.54 \\
\hline 1.84 & 50 & 53.26 & 28.49 & 1.81 & 50 & 50.28 & 25.28 \\
\hline 2.58 & 75 & 38.76 & 15.82 & 2.54 & 75 & 33.46 & 12.57 \\
\hline 3.68 & 100 & 38.31 & 14.21 & 3.63 & 100 & 32.78 & 12.19 \\
\hline
\end{tabular}


Table 2. Cont.

\begin{tabular}{|c|c|c|c|c|c|c|c|}
\hline \multicolumn{8}{|c|}{ Sorbent: Zeolite 10A } \\
\hline \multicolumn{4}{|c|}{ Sorbed Element: $\mathrm{Zn}^{2+}$} & \multicolumn{4}{|c|}{ Sorbed Element: $\mathrm{Cd}^{2+}$} \\
\hline \multicolumn{2}{|c|}{$\begin{array}{l}\text { Initial Concentration of } \mathrm{Zn}^{2+} \\
\text { in Solution Expressed: }\end{array}$} & \multirow{2}{*}{$\begin{array}{l}\% \\
\text { Sorption }\end{array}$} & \multirow{2}{*}{$\underset{[\mathrm{L} / \mathrm{kg}]}{\mathrm{K}_{\mathrm{d}}}$} & \multicolumn{2}{|c|}{$\begin{array}{l}\text { Initial Concentration of } \mathrm{Cd}^{2+} \\
\text { in Solution Expressed: }\end{array}$} & \multirow{2}{*}{$\begin{array}{c}\% \\
\text { Sorption }\end{array}$} & \multirow{2}{*}{$\underset{[\mathrm{L} / \mathbf{k g}]}{\mathrm{K}_{\mathrm{d}}}$} \\
\hline in $[\mathrm{cmol} / \mathrm{L}]$ & as $\%$ CEC & & & in $[\mathrm{cmol} / \mathrm{L}]$ & as $\%$ CEC & & \\
\hline 0.07 & 2 & 0.00 & n. c. ${ }^{*}$ & 0.07 & 2 & 16.66 & 4.17 \\
\hline 0.37 & 10 & 45.95 & 21.25 & 0.36 & 10 & 33.33 & 12.50 \\
\hline 0.74 & 20 & 43.24 & 19.05 & 0.73 & 20 & 45.20 & 20.63 \\
\hline 1.10 & 30 & 41.82 & 17.97 & 1.09 & 30 & 44.04 & 19.67 \\
\hline 1.84 & 50 & 47.28 & 22.42 & 1.81 & 50 & 52.49 & 27.62 \\
\hline 2.58 & 75 & 37.60 & 15.06 & 2.54 & 75 & 42.52 & 18.49 \\
\hline 3.68 & 100 & 31.52 & 11.51 & 3.63 & 100 & 37.74 & 15.15 \\
\hline \multicolumn{8}{|c|}{ Sorbent: Zeolite $13 X$} \\
\hline \multicolumn{4}{|c|}{ Sorbed Element: $\mathrm{Zn}^{2+}$} & \multicolumn{4}{|c|}{ Sorbed Element: $\mathrm{Cd}^{2+}$} \\
\hline \multicolumn{2}{|c|}{$\begin{array}{l}\text { Initial Concentration of } \mathrm{Zn}^{2+} \\
\text { in Solution Expressed: }\end{array}$} & \multirow[t]{2}{*}{$\begin{array}{c}\% \\
\text { Sorption }\end{array}$} & \multirow[t]{2}{*}{$\underset{[\mathrm{L} / \mathrm{kg}]}{\mathrm{K}_{\mathrm{d}}}$} & \multicolumn{2}{|c|}{$\begin{array}{l}\text { Initial Concentration of } \mathrm{Cd}^{2+} \\
\text { in Solution Expressed: }\end{array}$} & \multirow[t]{2}{*}{$\begin{array}{c}\% \\
\text { Sorption }\end{array}$} & \multirow[t]{2}{*}{$\begin{array}{c}\mathrm{K}_{\mathrm{d}} \\
{[\mathrm{L} / \mathrm{kg}]}\end{array}$} \\
\hline in $[\mathrm{cmol} / \mathrm{L}]$ & as $\%$ CEC & & & in $[\mathrm{cmol} / \mathrm{L}]$ & as \% CEC & & \\
\hline 0.05 & 2 & 100.00 & n. c. ${ }^{*}$ & 0.05 & 2 & 100.00 & n. c. ${ }^{*}$ \\
\hline 0.24 & 10 & 75.00 & 75.00 & 0.27 & 10 & 77.78 & 87.50 \\
\hline 0.48 & 20 & 68.75 & 55.00 & 0.53 & 20 & 67.92 & 52.94 \\
\hline 0.72 & 30 & 51.39 & 26.43 & 0.80 & 30 & 55.00 & 30.56 \\
\hline 1.20 & 50 & 40.83 & 17.25 & 1.33 & 50 & 45.11 & 20.55 \\
\hline 1.69 & 75 & 35.50 & 13.76 & 1.87 & 75 & 34.76 & 13.73 \\
\hline 2.41 & 100 & 26.14 & 8.85 & 2.67 & 100 & 23.60 & 7.72 \\
\hline
\end{tabular}

The comparative analysis of the above results showed that for both sorbed elements there was no one, clear behavior pattern of all tested minerals, which is related to their structural properties. In general, it can be stated that while the sorption capacity of natural zeolite and synthetic zeolite $3 \mathrm{~A}$ was greater towards $\mathrm{Zn}^{2+}$ than towards $\mathrm{Cd}^{2+}$, that tendency was reversed in the case of the synthetic Zeolites 10A and 13X.

Additionally, it was stated that in the case of the zeolite 13X for both tested elements, the level of sorption steadily decreased with increase of the initial concentration. The same was observed for the sorption of $\mathrm{Cd}^{2+}$ onto natural zeolite. The sorptive behavior of $\mathrm{Zn}^{2+}$ onto that zeolite was different: The sorption at low concentrations was at the level of $50 \%$, rising to $60 \%$, and then gradually decreasing with increasing concentration.

In the case of the zeolite 3A, the sorption pattern of both elements was similar: It was at the relatively constant levels in the range of $\sim 30 \%-\sim 60 \%$, without any clear increase-decrease trend.

A similar picture was obtained for the zeolite 10A, but in this case the sorption of both elements was low at low concentrations tested to sharply increase and then remain relatively stable at the level $\sim 30 \%-\sim 50 \%$.

The observed similarities and differences in sorption can be explained in terms of the mechanisms involved in the phenomena. It is generally acknowledged that the adsorption preferences of sorbent to sorbate may be due to the following factors [28]:

(1) Chemistry of the solution, such as $\mathrm{pH}$ and ionic strength;

(2) Properties of sorbate concentration, ionic size, ionic charge, ionic weight, and standard redox potential;

(3) Character of binding sites, functional groups, surface properties, etc. 
At the same time, it remains not fully clear how those factors may influence the preferences of the given sorbent towards the given sorbate, in particular in the multicomponent system.

The explanation of the observed phenomena was related, firstly, to the properties of sorbates.

As already indicated, $\mathrm{Cd}^{2+}$ and $\mathrm{Zn}^{2+}$ are the elements belonging to the group IIb of the periodic table. Therefore, having some key, from the point of view of their sorption onto zeolites, properties that are the same or similar, they have the same coordination number (6) and charge (+2) and similar diamagnetism and electronegativity, 1.7 for $\mathrm{Cd}^{2+}$ and 1.6 for $\mathrm{Zn}^{2+}$. As a result, it may be expected to have competition for the sorption sites. However, those two elements differ in other properties considered crucial for sorption onto zeolites, namely [37,62,63]:

(1) Atomic weight, for $\mathrm{Zn}^{2+} \mathrm{M}=65.38[\mathrm{~g} / \mathrm{mol}]$ and for $\mathrm{Cd}^{2+} \mathrm{M}=112.41[\mathrm{~g} / \mathrm{mol}]$;

(2) Hydrolysis constant, for $\mathrm{Zn}^{2+} \mathrm{K}_{\mathrm{a}}=9.0$ and for $\mathrm{Cd}^{2+} \mathrm{pK}_{\mathrm{a}}=10.1$;

(3) Ionic radius, for $\mathrm{Zn}^{2+}$ it is $0.074 \mathrm{~nm}$ and for $\mathrm{Cd}^{2+} 0.097 \mathrm{~nm}$;

(4) Hydrated ion radius, for $\mathrm{Zn}^{2+}$ it is $0.430 \mathrm{~nm}$ and for $\mathrm{Cd}^{2+} 0.426 \mathrm{~nm}$;

(5) Hydration energy, also called hydration enthalpy, being $-1955 \mathrm{~kJ} / \mathrm{mol}$ for $\mathrm{Zn}^{2+}$ and $-1807 \mathrm{~kJ} / \mathrm{mol}$ for $\mathrm{Cd}^{2+}$.

The generally low levels of sorption of both $\mathrm{Cd}^{2+}$ and $\mathrm{Zn}^{2+}$ onto tested zeolites may be explained by the radii of their hydrated ions and hydration energies. The necessary condition for the given cation to be bound to the sorption sites of the given sorbent is the removal of water molecules from the hydration sphere, which is related to the hydration enthalpy in the following manner: The higher the hydration energy, the lower the possibility of the removal of water molecules from hydration sphere and, hence, binding of the given cation to the sorption sites. $\mathrm{Zn}^{2+}$ and $\mathrm{Cd}^{2+}$ have high, in comparison to other bivalent metal cations hydration, energies, which explains the observed relatively low sorption levels and sharp decrease of sorption with increasing concentrations of sorbates [64].

The differences in hydration energies, hydrated ion radii, and atomic weights may also explain some preference in sorption of $\mathrm{Cd}^{2+}$ ions to $\mathrm{Zn}^{2+}$ ions observed for synthetic zeolites 10A and 13X, in line with findings reported in the literature on this subject [20,65].

The low sorption capacity of natural zeolite, in comparison to the synthetic zeolites, is in line with the other literature-reported results [66,67].

Because the results of the determination of the percentage of sorption and $K_{d}$ values did not provide a clear answer to the main problem, the identification of the most efficient of the four tested zeolites in simultaneous removal of $\mathrm{Zn}^{2+}$ and $\mathrm{Cd}^{2+}$ ions from the multisolute aqueous solutions, the obtained data were analyzed using three isotherm-based models. Freundlich, Langmuir, and DKR, demonstrated to be suitable for examination of sorption in multisolute systems [38].

Freundlich's isotherm provided the information on the strength and extent of sorption, as well as on the nature of the process. From the Langmuir isotherm, we derived the information on the maximum sorption capacity. Finally, the results of the DKR isotherm were used to identify the possible mechanism of sorption as well as sorption capacity.

Below are provided the results of the determination of the Freundlich and Langmuir isotherms. The numerical results are provided in Table 3 for Freundlich's isotherms and Table 4 for Langmuir's isotherms. 
Table 3. The numerical parameters of the determined Freundlich isotherms.

\begin{tabular}{|c|c|c|c|c|c|c|c|c|}
\hline \multirow{3}{*}{ Sorbent } & \multirow{3}{*}{$\begin{array}{l}\text { Sorbed } \\
\text { Element }\end{array}$} & \multicolumn{4}{|c|}{ Parameters of Freundlich Isotherm } & \multicolumn{3}{|c|}{$\begin{array}{c}\text { Statistical Parameters of } \\
\text { the Isotherm }\end{array}$} \\
\hline & & \multicolumn{2}{|c|}{ Adsorption Constant $K_{\mathrm{f}}[\mathrm{L} / \mathrm{kg}]$} & \multicolumn{2}{|c|}{$1 / n$} & \multirow{2}{*}{ SD } & \multirow[t]{2}{*}{$\mathbf{r}$} & \multirow{2}{*}{$\mathbf{R}^{2}$} \\
\hline & & Value & SD & Value & SD & & & \\
\hline Natural & $\mathrm{Zn}^{2+}$ & 8.82 & 0.311 & 0.609 & 0.034 & 0.229 & 0.9965 & 0.9931 \\
\hline Zeolite & $\mathrm{Cd}^{2+}$ & 4.15 & 0.245 & 0.426 & 0.057 & 0.256 & 0.9846 & 0.9694 \\
\hline Zeolite & $\mathrm{Zn}^{2+}$ & 21.96 & 1.602 & 0.564 & 0.096 & 3.566 & 0.9665 & 0.9342 \\
\hline $3 \mathrm{~A}$ & $\mathrm{Cd}^{2+}$ & 17.94 & 1.401 & 0.572 & 0.101 & 3.130 & 0.9650 & 0.9311 \\
\hline Zeolite & $\mathrm{Zn}^{2+}$ & 16.85 & 1.282 & 0.666 & 0.100 & 2.803 & 0.9734 & 0.9475 \\
\hline $10 \mathrm{~A}$ & $\mathrm{Cd}^{2+}$ & 19.50 & 1.553 & 0.763 & 0.116 & 3.332 & 0.9722 & 0.9452 \\
\hline Zeolite & $\mathrm{Zn}^{2+}$ & 13.64 & 0.450 & 0.327 & 0.037 & 0.906 & 0.9901 & 0.9803 \\
\hline $13 X$ & $\mathrm{Cd}^{2+}$ & 14.54 & 0.676 & 0.274 & 0.048 & 1.424 & 0.9795 & 0.9595 \\
\hline
\end{tabular}

Table 4. The numerical parameters of the determined Langmuir isotherms.

\begin{tabular}{|c|c|c|c|c|c|c|c|c|c|}
\hline \multirow{3}{*}{ Sorbent } & \multirow{3}{*}{$\begin{array}{l}\text { Sorbed } \\
\text { Element }\end{array}$} & \multicolumn{5}{|c|}{ Parameters of Langmuir Isotherm } & \multicolumn{3}{|c|}{$\begin{array}{c}\text { Statistical Parameters of } \\
\text { the Isotherm }\end{array}$} \\
\hline & & \multicolumn{2}{|c|}{$\mathrm{K}_{\mathrm{L}}[\mathrm{L} / \mathrm{kg}]$} & \multicolumn{2}{|c|}{$\mathbf{K}_{\mathrm{L}} * \mathbf{N}$} & \multirow{2}{*}{$\begin{array}{c}\mathrm{N} \\
{[\mathrm{cmol} / \mathrm{kg}]}\end{array}$} & \multirow{2}{*}{ SD } & \multirow{2}{*}{$\mathbf{r}$} & \multirow{2}{*}{$\mathbf{R}^{2}$} \\
\hline & & Value & SD & Value & SD & & & & \\
\hline Natural & $\mathrm{Zn}^{2+}$ & 2.09 & 0.609 & 24.18 & 3.531 & 11.58 & 0.382 & 0.9903 & 0.9807 \\
\hline Zeolite & $\mathrm{Cd}^{2+}$ & 4.59 & 1.785 & 21.08 & 5.599 & 4.60 & 0.356 & 0.9697 & 0.9403 \\
\hline Zeolite & $\mathrm{Zn}^{2+}$ & 1.01 & 0.400 & 48.19 & 11.264 & 47.59 & 3.170 & 0.9736 & 0.9480 \\
\hline $3 \mathrm{~A}$ & $\mathrm{Cd}^{2+}$ & 0.87 & 0.343 & 36.62 & 8.230 & 41.8 & 2.634 & 0.9753 & 0.9513 \\
\hline Zeolite & $\mathrm{Zn}^{2+}$ & 0.53 & 0.189 & 27.72 & 4.680 & 52.46 & 2.091 & 0.9853 & 0.9708 \\
\hline $10 \mathrm{~A}$ & $\mathrm{Cd}^{2+}$ & 0.35 & 0.183 & 27.97 & 5.305 & 79.34 & 2.816 & 0.9802 & 0.9609 \\
\hline Zeolite & $\mathrm{Zn}^{2+}$ & 4.95 & 1.266 & 83.83 & 16.936 & 16.93 & 1.026 & 0.9861 & 0.9724 \\
\hline $13 X$ & $\mathrm{Cd}^{2+}$ & 5.92 & 1.188 & 105.75 & 17.313 & 17.87 & 0.927 & 0.9914 & 0.9828 \\
\hline
\end{tabular}

In graphical form, the isotherms are presented in Figures 2 and 3. Each figure presents a set of the individual isotherms, generated by the tool CurveExpert Pro 2.5.6. The colored bands represent the confidence bands for a 95\% level of confidence, darker pink, and $90 \%$ level of confidence, lighter pink.

On the basis of the analysis of the goodness of fit (visual inspection of plotted isotherms and the analysis of the $r$ and $R^{2}$ values) for each isotherm, it can be stated that both models well complied with the experimental data. The comparative analysis of the determined values of the $r$ and $R^{2}$ values showed that in general Freundlich's model better characterized the adsorption of $\mathrm{Zn}^{2+}$ and $\mathrm{Cd}^{2+}$ onto the tested minerals. For that reason, its parameters were selected to characterize the strength and extent of sorption.

The analysis of the strength of sorption, based on the determined $\mathrm{K}_{\mathrm{f}}$ values, showed that it cannot be stated for all four tested zeolites whose element, $\mathrm{Zn}^{2+}$ or $\mathrm{Cd}^{2+}$, was sorbed more strongly, hence, which displayed higher affinity towards the tested aluminosilicates. The stronger sorption of $\mathrm{Zn}^{2+}$ in comparison to that of $\mathrm{Cd}^{2+}$ was observed in case of natural zeolite and zeolite $3 \mathrm{~A}$, while $\mathrm{Cd}^{2+}$ was sorbed more strongly than $\mathrm{Zn}^{2+}$ on zeolite $10 \mathrm{~A}$ and zeolite 13A. It has to be indicated that in the case of zeolite $13 \mathrm{X}$ the difference in sorption strength of both elements was not that big, as observed for the other tested mineral sorbents. The observed differences may be attributed to some specific properties of the sorbed ions, indicated in the available literature, atomic weight, ion radius, hydratation energy, and specific properties of the aqua complexes of each ion. 


\section{Isotherms for $\mathrm{Zn}^{2+}$}
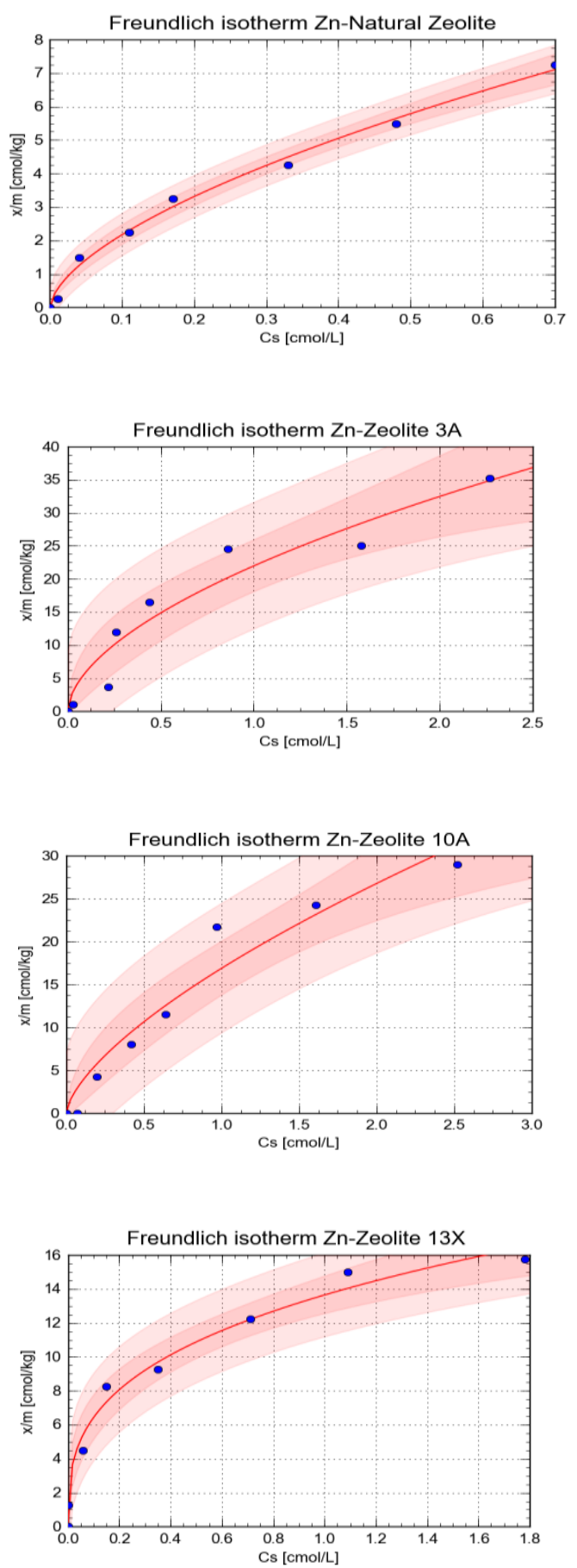

\section{Isotherms for $\mathrm{Cd}^{2+}$}
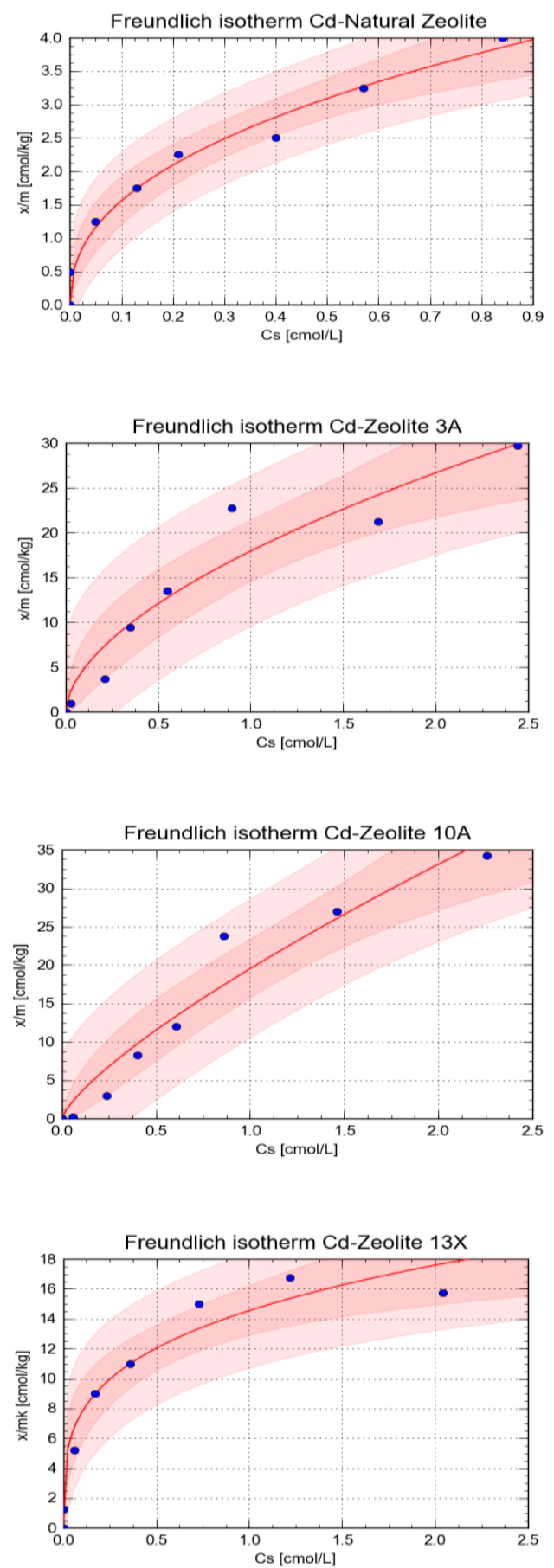

Figure 2. The Freundlich isotherms obtained in the study for sorption of $\mathrm{Zn}^{2+}$ and $\mathrm{Cd}^{2+}$ onto tested natural and synthetic zeolites. 
Isotherms for $\mathrm{Zn}^{2+}$
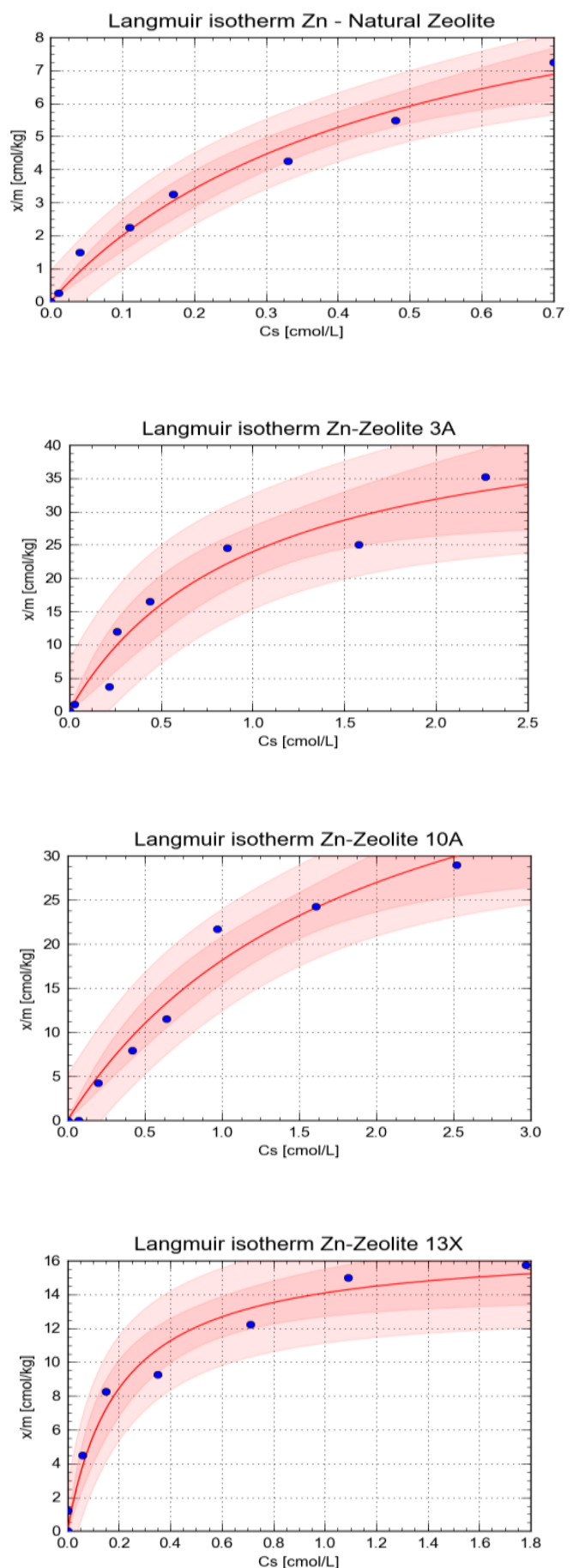

\section{Isotherms for $\mathrm{Cd}^{2+}$}
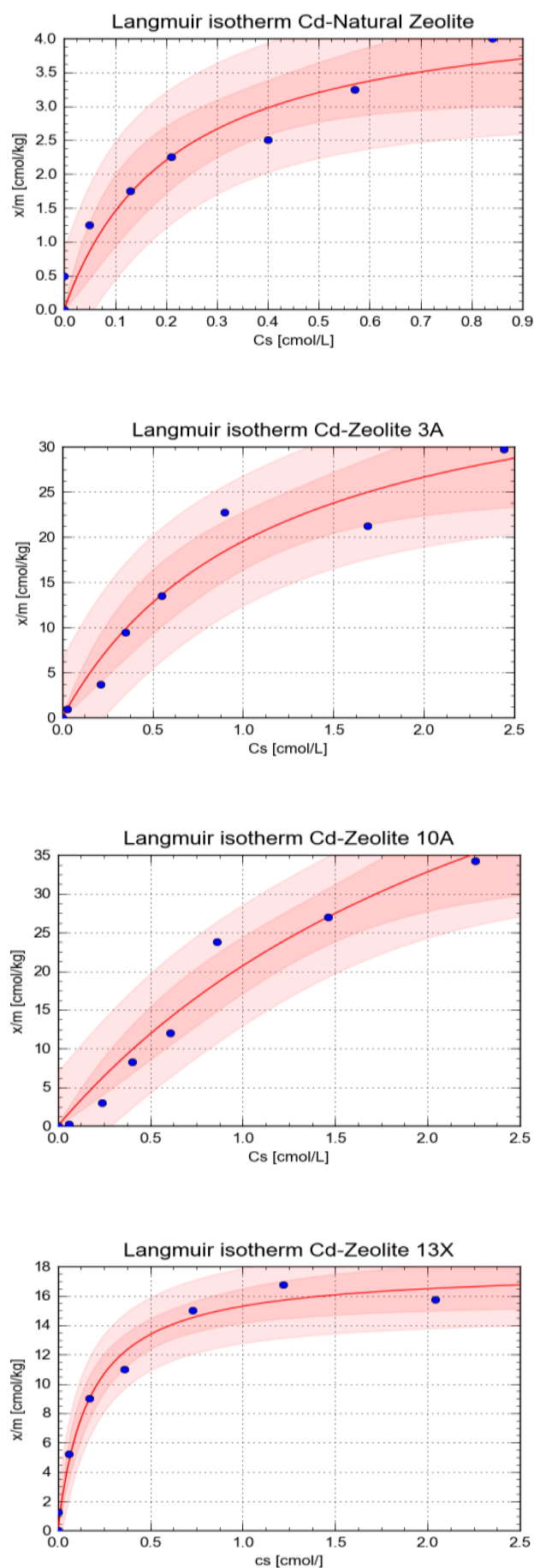

Figure 3. The Langmuir isotherms obtained in the study for sorption of $\mathrm{Zn}^{2+}$ and $\mathrm{Cd}^{2+}$ onto tested natural and synthetic zeolites.

It was also stated that the strongest sorption of both $\mathrm{Zn}^{2+}$ and $\mathrm{Cd}^{2+}$ occurred on synthetic zeolites $3 \mathrm{~A}$ and $10 \mathrm{~A}$, while the weakest was on the natural zeolite.

When arranged in order from the strongest to the weakest the strength and extent of sorption followed the order: for $\mathrm{Zn}^{2+}$, 
and for $\mathrm{Cd}^{2+}$,

\section{Zeolite 10A > Zeolite 3A > Zeolite 13X > Natural Zeolite}

The values of $1 / n$, the parameter informing about the nature of the process, was always below 0.8 , indicating that the sorption of both $\mathrm{Zn}^{2+}$ and $\mathrm{Cd}^{2+}$ on all tested minerals was generally preferential and either favorable or pseudolinear [68]. When arranged from the highest to the lowest, the values of $1 / \mathrm{n}$, and, hence, the decrease of the linearity of sorption followed the order: for $\mathrm{Zn}^{2+}$,

\section{Zeolite 10A > Natural Zeolite > Zeolite 3A > Zeolite 13X}

and for $\mathrm{Cd}^{2+}$,

\section{Zeolite 10A > Zeolite 3A > Natural Zeolite > Zeolite 13X}

This may indicate, in the case of the combined pollution of the aquatic environment with those two elements, synthetic zeolite 10A would remain most efficient either over a much broader range of concentrations or in the case of prolonged exposure to a polluted medium, while the least efficient is expected to be the synthetic zeolite 13X. The sorption strength, characterized by the Freundlich adsorption constant, was well correlated with the maximum sorption capacity $\mathrm{N}$, the parameter determined using the Langmuir sorption isotherm. It was stated that for both $\mathrm{Zn}^{2+}$ and $\mathrm{Cd}^{2+}$ this parameter was higher for synthetic zeolites than for the natural zeolite and that the A-type zeolites had much greater sorption capacity than the $\mathrm{X}$-type zeolite.

It may be also stated that using the values of $\mathrm{K}_{\mathrm{f}}$ from the Freundlich isotherm and $\mathrm{N}$ from Langmuir's isotherm, indicators of the selectivity of the tested zeolites, it may be postulated that while natural zeolite and zeolite $3 \mathrm{~A}$ displayed higher selectivity towards $\mathrm{Zn}^{2+}$ ions, the synthetic zeolites $10 \mathrm{~A}$ and 13X showed preference towards $\mathrm{Cd}^{2+}$ ions.

When arranged in order from the highest to the lowest, the Langmuir's maximum sorption capacity $\mathrm{N}$ followed the order: For both $\mathrm{Zn}^{2+}$ and $\mathrm{Cd}^{2+}$,

\section{Zeolite 10A > Zeolite 3A > Zeolite 13X > Natural Zeolite}

It was also indicated that, while for the natural zeolite the difference in $\mathrm{N}$ values was significant, about 2.5 times in favor of $\mathrm{Zn}^{2+}$, in the case of the tested synthetic zeolites the differences in $\mathrm{N}$ values were not that big, and followed the order: Zeolite $10 \mathrm{~A}\left(51 \%\right.$ difference in favor of $\left.\mathrm{Cd}^{2+}\right)>$ zeolite $3 \mathrm{~A}$ $\left(11 \%\right.$ difference in favor of $\left.\mathrm{Zn}^{2+}\right)>$ zeolite $13 \mathrm{X}\left(5 \%\right.$ difference in favor of $\left.\mathrm{Cd}^{2+}\right)$.

The results of the determination of the parameters of the DKR isotherm are presented below, in numerical form in Table 5.

Table 5. The parameters of the determined DKR (Dubynin-Karganer-Radushkevich) isotherms.

\begin{tabular}{|c|c|c|c|c|c|c|c|c|c|c|}
\hline \multirow{3}{*}{ Sorbent } & \multirow{3}{*}{$\begin{array}{l}\text { Sorbed } \\
\text { Element }\end{array}$} & \multicolumn{6}{|c|}{ Parameters of the DKR Isotherm } & \multicolumn{3}{|c|}{$\begin{array}{c}\text { Statistical Parameters of } \\
\text { the Isotherm }\end{array}$} \\
\hline & & \multicolumn{2}{|c|}{$\ln X_{\mathrm{m}}$} & \multicolumn{2}{|c|}{$\beta\left[\mathrm{mol}^{2} / \mathrm{kJ}^{2}\right]$} & \multirow{2}{*}{$\begin{array}{c}X_{\mathrm{m}} \\
{[\mathrm{cmol} / \mathrm{kg}]}\end{array}$} & \multirow{2}{*}{$\begin{array}{c}E \\
{[\mathrm{~kJ} / \mathrm{mol}]}\end{array}$} & \multirow{2}{*}{ SD } & \multirow{2}{*}{$\mathbf{r}$} & \multirow{2}{*}{$\mathbf{R}^{2}$} \\
\hline & & Value & SD & Value & SD & & & & & \\
\hline Natural & $\mathrm{Zn}^{2+}$ & 1.852 & 0.095 & -0.02554 & 0.00017 & 6.37 & 4.425 & 0.1832 & 0.9890 & 09781 \\
\hline Zeolite & $\mathrm{Cd}^{2+}$ & 1.256 & 0.096 & -0.02046 & 0.0036 & 3.51 & 4.94 & 0.156 & 0.9433 & 0.8898 \\
\hline Zeolite & $\mathrm{Zn}^{2+}$ & 3.315 & 0.238 & -0.04508 & 0.0018 & 27.51 & 3.30 & 0.513 & 0.9285 & 0.8621 \\
\hline $3 \mathrm{~A}$ & $\mathrm{Cd}^{2+}$ & 2.954 & 0.222 & -0.04285 & 0.0076 & 19.18 & 3.42 & 0.486 & 0.9301 & 0.8651 \\
\hline Zeolite & $\mathrm{Zn}^{2+}$ & 3.262 & 0.138 & -0.1039 & 0.0154 & 26.10 & 2.19 & 0.237 & 0.9588 & 0.9194 \\
\hline $10 \mathrm{~A}$ & $\mathrm{Cd}^{2+}$ & 3.265 & 0.179 & -0.09952 & 0.00909 & 26.17 & 2.29 & 0.375 & 0.9802 & 0.9608 \\
\hline Zeolite & $\mathrm{Zn}^{2+}$ & 2.680 & 0.068 & -0.02449 & 0.00308 & 14.59 & 4.52 & 0.124 & 0.9717 & 0.9442 \\
\hline $13 X$ & $\mathrm{Cd}^{2+}$ & 2.774 & 0.048 & -0.02368 & 0.00216 & 16.03 & 4.59 & 0.089 & 0.9838 & 0.9679 \\
\hline
\end{tabular}


The analysis of the goodness of fit of each isotherm, based on the analysis of $\mathrm{R}^{2}$ and $\mathrm{r}$ coefficients, showed that at least acceptable fits were obtained for each combination mineral, sorbed element, which indicated, as it was in the case of Freundlich and Langmuir sorption models, that the DKR was correctly selected as an adequate model characterizing sorption in the examined test systems.

The analysis of the constant $X_{m}$, characterizing the maximum sorption capacity, showed that that parameter was higher for sorption of $\mathrm{Zn}^{2+}$ for the natural zeolite and synthetic zeolite $3 \mathrm{~A}$, while the opposite situation was observed for the synthetic zeolite 13X. In the case of the synthetic zeolite 10A, the values of $X_{m}$ for both elements were almost identical.

When arranged in order from the highest to the lowest, the maximum sorption capacity $X_{m}$ followed the order: for $\mathrm{Zn}^{2+}$,

\section{Zeolite 3A > Zeolite 10A > Zeolite 13X > Natural Zeolite}

and for $\mathrm{Cd}^{2+}$,

\section{Zeolite 10A > Zeolite 3A > Zeolite 13X > Natural Zeolite}

For $\mathrm{Zn}^{2+}$, that order was very similar, and for $\mathrm{Cd}^{2+}$, it was identical to that determined for respective $\mathrm{N}$ values in the Langmuir isotherms, but the values were different, which can be explained by the fact that while Langmuir's isotherm examines the process of sorption in a more general way, the DKR isotherm is more focused on the examination of sorption in micropores. When the ratio $\mathrm{N}: \mathrm{X}_{\mathrm{m}}$ was calculated, $\mathrm{N}$ was always higher than $\mathrm{X}_{\mathrm{m}}$. The numerical results of that analysis, the calculated ratios $\mathrm{N}: \mathrm{X}_{\mathrm{m}}$, are provided below in the Table 6 .

The values of the energy of sorption of $\mathrm{Zn}^{2+}$ on the tested sorbents were in the range of $2.19-4.52[\mathrm{~kJ} / \mathrm{mol}]$ and those for $\mathrm{Cd}^{2+}$ were in the range $2.29-4.94[\mathrm{~kJ} / \mathrm{mol}]$.

That parameter provides the information about the possible mechanism of sorption $[37,60,61]$. That was done using the following classification of the postulated mechanisms of sorption in relation to the determined energy: For $\mathrm{E}<8 \mathrm{~kJ} / \mathrm{mol}$, the possible mechanism of adsorption was physical sorption; for E being in the range of 8 and $16 \mathrm{~kJ} / \mathrm{mol}$, it can be explained by ion exchange; for $\mathrm{E}>16 \mathrm{~kJ} / \mathrm{mol}$, the possible mechanism was chemical sorption stronger than the ion exchange.

On its basis, it can be stated for both elements the sorption mechanism for all tested minerals was physisorption. Although, in principle, ion exchange was indicated as a primary mechanism of sorption of metal ions onto aluminosilicate minerals, including zeolites, in the case of sorption from multicomponent solutions the mechanism could switch to the physisorption, which in turn may be attributed to the higher competition for the low-energy sorption sites [27].

When arranged in order from the highest to the lowest the sorption energy E followed the order: for $\mathrm{Zn}^{2+}$,

$$
\text { Zeolite 13X > Natural Zeolite }>\text { Zeolite 3A > Zeolite 10A }
$$

and for $\mathrm{Cd}^{2+}$,

$$
\text { Natural Zeolite }>\text { Zeolite 13X > Zeolite 3A > Zeolite 10A. }
$$

Additionally, the values of the maximum adsorption capacity towards $\mathrm{Zn}^{2+}$ and $\mathrm{Cd}^{2+}$ ions, determined for each tested mineral using Langmuir's and DKR isotherms, were collected in a single table, Table 6 below. In order to render them comparable with the values reported in the literature, those values were converted to $[\mathrm{mmol} / \mathrm{g}]$ and to $[\mathrm{mg} / \mathrm{g}]$, units most commonly used in the scientific literature of the subject. The second conversion was performed using the adequate values of molar weights, $65.38 \mathrm{~g} / \mathrm{mol}$ for $\mathrm{Zn}$ and $112.41 \mathrm{~g} / \mathrm{mol}$ for $\mathrm{Cd}$. When compared to the values provided in other scientific papers on the same subject [19,22-24,26,69-71], the tested minerals were demonstrated to display similar or greater sorption capacity comparing to the similar sorbents and other novel materials tested to remove heavy metals from wastewater effluents. That makes them a good, cost-efficient, and environmentally friendly alternative in the processes of purification of water polluted with heavy metal ions. 
Table 6. The values of maximum sorption capacity in Langmuir's $(N)$ and DKR $\left(X_{m}\right)$ isotherms and their ratios.

\begin{tabular}{|c|c|c|c|c|c|c|c|c|}
\hline \multirow[t]{2}{*}{ Sorbent } & \multirow{2}{*}{$\begin{array}{l}\text { Sorbed } \\
\text { Element }\end{array}$} & \multicolumn{3}{|c|}{$\begin{array}{c}\text { Maximum Sorption Capacity } \\
\text { N-Langmuir's Isotherm, Expressed in: }\end{array}$} & \multicolumn{3}{|c|}{$\begin{array}{c}\text { Maximum Sorption Capacity } \\
X_{m}-\text { DKR Isotherm, Expressed in: }\end{array}$} & \multirow{2}{*}{$\begin{array}{l}\text { Ratio } \\
\mathrm{N}: \mathrm{X}_{\mathrm{m}}\end{array}$} \\
\hline & & {$[\mathrm{cmol} / \mathrm{kg}]$} & {$[\mathrm{mmol} / \mathrm{g}]$} & {$[\mathrm{mg} / \mathrm{g}]$} & {$[\mathrm{cmol} / \mathrm{kg}]$} & {$[\mathrm{mmol} / \mathrm{g}]$} & [mg/g] & \\
\hline \multirow{2}{*}{$\begin{array}{l}\text { Natural } \\
\text { Zeolite }\end{array}$} & $\mathrm{Zn}^{2+}$ & 11.58 & 0.1158 & 7.57 & 6.37 & 0.0637 & 4.16 & $1.82: 1$ \\
\hline & $\mathrm{Cd}^{2+}$ & 4.60 & 0.0460 & 5.17 & 3.51 & 0.0351 & 3.95 & $1.31: 1$ \\
\hline \multirow{2}{*}{ Zeolite 3A } & $\mathrm{Zn}^{2+}$ & 47.59 & 0.4759 & 31.11 & 27.51 & 0.2751 & 17.99 & $1.73: 1$ \\
\hline & $\mathrm{Cd}^{2+}$ & 41.8 & 0.4180 & 46.99 & 19.18 & 0.1981 & 22.27 & $2.18: 1$ \\
\hline \multirow{2}{*}{ Zeolite 10A } & $\mathrm{Zn}^{2+}$ & 52.46 & 0.5246 & 34.30 & 26.10 & 0.2610 & 17.06 & 2.01:1 \\
\hline & $\mathrm{Cd}^{2+}$ & 79.34 & 0.7934 & 89.19 & 26.17 & 0.2617 & 29.42 & $3.03: 1$ \\
\hline \multirow{2}{*}{ Zeolite 13X } & $\mathrm{Zn}^{2+}$ & 16.93 & 0.1693 & 11.07 & 14.59 & 0.1459 & 9.54 & $1.16: 1$ \\
\hline & $\mathrm{Cd}^{2+}$ & 17.87 & 0.1787 & 20.09 & 16.03 & 0.1603 & 18.02 & $1.11: 1$ \\
\hline
\end{tabular}

\section{Conclusions}

On the basis of the obtained results it may be stated that:

(1) The tested synthetic zeolites, 3A, 10Am and 13X, were more efficient in the simultaneous removal of $\mathrm{Cd}^{2+}$ and $\mathrm{Zn}^{2+}$ ions from aqueous solutions than the tested natural zeolite, which may be related to their higher mineralogical homogeneity;

(2) The analysis of the performance of the tested zeolites, based on the analysis of the parameters of sorption isotherm models, showed that the most efficient in simultaneous removal of $\mathrm{Cd}^{2+}$ and $\mathrm{Zn}^{2+}$ ions from aqueous solutions were zeolite $3 \mathrm{~A}$ and zeolite 10A. Therefore, those two sorbents should be recommended to be used for rapid reduction of the level of pollution with those two elements and their spreading in the environment;

(3) Zeolite 10A displayed a relatively high and constant sorption capacity over a broader range of concentrations, which indicates that it will be efficient in coping with prolonged low- and medium-level pollution of aquatic environment with cadmium and zinc;

(4) The identified, on the basis of the adsorption energies, mechanism of sorption was, for all tested zeolites, physisorption, which may be explained by the fact that the sorption was examined in a multisolute system;

(5) The synthetic zeolites $10 \mathrm{~A}$ and $13 \mathrm{X}$ displayed higher selectivity to $\mathrm{Cd}^{2+}$ than to $\mathrm{Zn}^{2+}$, while in the case of the natural zeolite and synthetic zeolite $3 \mathrm{~A}$ that relationship was reversed.

Author Contributions: B.G.: Conceptualization, methodology, investigation, supervision, and writing review and editing; B.K.-S.: Conceptualization, methodology, investigation, validation; I.K.: Formal analysis, visualization, writing original draft, review and editing. All authors have read and agreed to the published version of the manuscript.

Funding: This research received no external funding.

Acknowledgments: This research was supported by statutory activity of the University of Life Sciences and Institute of Environmental Protection-National Research Institute. The authors would like to thank Zbigniew Zagórski for identification of zeolites.

Conflicts of Interest: The authors declare no conflict of interest.

\section{References}

1. Karlaviciene, V.; Svendine, S.; Marciulioniene, D.E.; Randerson, P.; Rimeika, M.; Hogland, W. The impact of storm water runoff on a small urban stream. J. Soils Sediment. 2009, 9, 6-12. [CrossRef]

2. Lynch, S.F.L.; Batty, L.C.; Byrne, P. Environmental Risk of Metal Mining Contaminated River Bank Sediment at Redox-Transitional Zones. Minerals 2014, 4, 52-73. [CrossRef]

3. Newman, M.C. Fundamentals of Ecotoxicology. The Science of Pollution, 4th ed.; CRC Press, Taylor \& Francis Group: Boca Raton, FL, USA, 2015; passim. 
4. Hudson-Edwards, K.A.; Dold, E. Mine Waste Characterization, Management and Remediation. Minerals 2015, 5, 82-85. [CrossRef]

5. Ramesh, K.; Elango, L. Impact of Groundwater Quality from Industrial East Coastal Town, Southern India. Int. J. Eng. Res. Appl. 2014, 4, 346-354.

6. Pierzynski, G.M.; Sims, T.J.; Vance, G.F. Soils and Environmental Quality, 2nd ed.; CRC Press, Taylor \& Francis Group: Boca Raton, FL, USA, 2000; passim.

7. Kabata-Pendias, A. Trace Elements in Soils and Plants, 3nd ed.; CRC Press: Boca Raton, FL, USA, 2001 ; passim. [CrossRef]

8. Kabata-Pendias, A.; Mukherjee, A.B. Trace Elements from Soil to Human; Springer: Berlin, Germany, 2007; passim. [CrossRef]

9. Alloway, B.J. (Ed.) Heavy Metals in Soils, 3nd ed.; Springer: Berlin, Germany, 2013; passim. [CrossRef]

10. Frausto da Silva, J.J.R.; Williams, R.J.P. The Biological Chemistry of the Elements. The Inorganic Chemistry of Life, 2nd ed.; Oxford University Press: Oxford, UK, 2001; passim.

11. Blanchard, G.; Maunaye, M.; Martin, G. Removal of heavy metals from waters by means of natural zeolites. Water Res. 1984, 18, 1501-1507. [CrossRef]

12. Gworek, B. Inactivation of cadmium in contaminated Soils using synthetic zeolites. Environ. Pollut. 1992, 75, 269-271. [CrossRef]

13. Gworek, B. Inactivation of lead anthropogenic soils by synthetic zeolites and plants growth. Plant Soil 1992, 143, 71-74. [CrossRef]

14. Gworek, B. The Effect of Zeolites on Cooper Uptake by plants Growing in Contaminated Soils. J. Incl. Phenom. Mol. Recognit. Chem. 1993, 15, 1-7. [CrossRef]

15. Oste, L.A.; Lexmond, T.M.; Van Riemsdijk, W.H. Metal Immobilization in Soils Using Synthetic Zeolites. J. Environ. Qual. 2002, 31, 813-821. [CrossRef]

16. Wingenfelder, U.; Hansen, C.; Furrer Schulin, R. Removal of Heavy Metals from Mine Waters by Natural Zeolites. Environ. Sci. Technol. 2005, 39, 4606-4613. [CrossRef]

17. Sprynskyy, M.; Buszewski, B.; Terzyk, A.P.; Namieśnik, J. Study of the selection mechanism of heavy metal $\left(\mathrm{Pb}^{2+}, \mathrm{Cu}^{2+}, \mathrm{Ni}^{2+}\right.$, and $\left.\mathrm{Cd}^{2+}\right)$ adsorption on clinoptilolite. J. Colloid Interface Sci. 2006, 304, 21-28. [CrossRef]

18. Usman, A.; Yakov, R.A.; Kuzyakov, Y.; Lorenz, K.; Stahr, K. Remediation of a soil contaminated with heavy metals by immobilizing compounds. J. Plant Nutr. Soil Sci. 2006, 169, 205-212. [CrossRef]

19. Bhattacharyya, K.G.; Gupta, S.S. Adsorptive accumulation of $\mathrm{Cd}(\mathrm{II}), \mathrm{Co}(\mathrm{II}), \mathrm{Cu}$ (II), $\mathrm{Pb}$ (II), and Ni(II) from water on montmorillonite: Influence of acid activation. J. Colloid Interface Sci. 2007, 310, 411-424. [CrossRef]

20. Ibrahim, H.S.; Jamil, T.; Hegazy, E.Z. Application of Zeolite Prepared from Egyptian Kaolin for the Removal of Heavy Metals: II. Isotherm Models. J. Hazard. Mater. 2010, 182, 842-847. [CrossRef]

21. Karatas, M. Removal of $\mathrm{Pb}(\mathrm{II})$ from water by natural zeolitic tuff: Kinetics and thermodynamics. J. Hazard. Mater. 2012, 199-200, 383-389. [CrossRef]

22. Zhao, Y. Review of the Natural, Modified, and Synthetic Zeolites for Heavy Metals Removal from Wastewater. Environ. Eng. Sci. 2016, 33, 443-454. [CrossRef]

23. El-Azim, H.A.; Mourad, F.A. Removal of Heavy Metals Cd (II), Fe (III) and Ni (II), from Aqueous Solutions by Natural (Clinoptilolite) Zeolites and Application to Industrial Wastewater. Asian J. Environ. Ecol. 2018, 7, 1-13. [CrossRef]

24. Fanta, F.T.; Dubale, A.A.; Bebizuh, D.F.; Atlabachew, M. Copper doped zeolite composite for antimicrobial activity and heavy metal removal from waste water. BMC Chem. 2019, 13, 12. [CrossRef]

25. Ahmaruzzaman, M. Industrial Wastes as Low-Cost Potential Adsorbents fo4r the Treatment of Wastewater Laden with Heavy Metals. Adv. Colloid Interface Sci. 2011, 166, 36-59. [CrossRef]

26. Uddin, M.K. A review on the adsorption of heavy metals by clay minerals, with special focus on the past decade. Chem. Eng. J. 2017, 308, 438-462. [CrossRef]

27. Qin, F.; Wen, B.; Shan, X.-Q.; Xie, Y.N.; Liu, T.; Zhang, S.Z.; Khan, S.U. Mechanisms of competitive adsorption of $\mathrm{Pb}, \mathrm{Cu}$ and $\mathrm{Cd}$ on peat. Environ. Pollut. 2006, 144, 669-680. [CrossRef]

28. Mahamadi, C.; Nharingo, T. Competitive adsorption of $\mathrm{Pb}^{2+}, \mathrm{Cd}^{2+}$ and $\mathrm{Zn}^{2+}$ ions onto Eichhornia crassipes in binary and ternary systems. Bioresour. Technol. 2010, 101, 859-864. [CrossRef]

29. Eloussaief, M.; Hamza, W.; Kallel, N.; Bnezina, M. Wastewaters Decontamination: Mechanisms of Pb(II), Zn (II) and Cd (II) Competitive Adsorption on Tunisian Smectite in Single and Multi-Solute Systems. Environ. Prog. Sustain. Energy 2013, 32, 229-238. [CrossRef] 
30. OECD. OECD Guideline for the Testing of Chemicals No. 106 Adsorption-Desorption Using a Batch Equilibrium Method; OECD: Paris, France, 2000. [CrossRef]

31. Balaz, B.; Alacova, A.; Briancin, J. Sensivity of Freundlich equation constant $1 / \mathrm{n}$ for zinc sorption on changes introduced by calcite by mechanical activation. Chem. Eng. J. 2005, 114, 115-121. [CrossRef]

32. Toth, J. Uniform interpretation of gas/solid adsorption. Adv. Colloid Interface Sci. 1995, 55, 1-239. [CrossRef]

33. Otake, Y.; Kalili, N.; Chang, T.H.; Furuya, E. Relationship between Freundlich-type equation constants and molecular orbital properties. Sep. Purif. Technol. 2004, 39, 67-72. [CrossRef]

34. Kupiec, K.; Georgiou, A. Analysis of thermal effects in a spherical adsorbent pellet. Int. J. Heat Mass Transf. 2005, 48, 5047-5057. [CrossRef]

35. Milonjic, S.K. A consideration of the corrected calculation of thermodynamic parameters of adsorption. J. Serb. Chem. Soc. 2007, 72, 1363-1367. [CrossRef]

36. Rudzinski, W.; Plazinski, W. Theoretical description of the kinetics of solute adsorption at heterogeneous solid/solution interfaces. On the possibility of distinguishing between the diffusional and surface reaction kinetics models. Appl. Surf. Sci. 2007, 253, 5827-5840. [CrossRef]

37. Mobacherpour, I.; Salahi, E.; Pazouki, M. Comparative of the removal of $\mathrm{Pb}^{2+}, \mathrm{Cd}^{2+}$ and $\mathrm{Ni}^{2+}$ by nano crystallite hydroxyapatite from aqueous solutions: Adsorption isotherms study. Arab. J. Chem. 2012, 5, 439-446. [CrossRef]

38. Allen, S.J.; Mckay, G.; Porter, J.F. Adsorption isotherm models for basic dye adsorption by peat in single and binary component system. Colloid Interface Sci. 2004, 280, 322-333. [CrossRef]

39. Yang, K.; Wang, X.; Zhu, L.; Xing, B. Competitive Sorption of Pyrene, Phenantrene and Naphtalene on Multiwalled Carbon Nanotubes. Environ. Sci. Technol. 2006, 40, 5804-5810. [CrossRef]

40. Swayampakula, K.; Boddu, V.M.; Nadavala, S.K.; Abburi, K.M. Competitive adsorption of Cu(II), Co (II) and $\mathrm{Ni}$ (II) from their binary and tertiary aqueous solutions using chitosan-coated perlite beads as biosorbent. J. Hazard. Mater. 2009, 170, 680-689. [CrossRef]

41. Tofighy, M.A.; Mohammadi, T. Adsorption of divalent heavy metal ions from water using carbon nanotube sheets. J. Hazard. Mater. 2011, 185, 140-147. [CrossRef]

42. Bouhamed, P.; Elouear, Z.; Bouzid, J.; Ouddane, B. Multi-component adsorption of copper, nickel and zinc from aqueous solutions onto activated carbon prepared from date stones. Environ. Sci. Pollut. Res. 2016, 23, 15801-15806. [CrossRef]

43. Yurekli, Y. Determination of adsorption characteristics of synthetic NaX nanoparticles. J. Hazard. Mater. 2019, 378, 120743. [CrossRef]

44. Ho, Y.-S. Selection of optimum sorption isotherm. Carbon 2004, 42, 2115-2116. [CrossRef]

45. Kumar, K.V.; Sivanesan, S. Prediction of optimum sorption isotherm: Comparison of linear and non-linear method. J. Hazard. Mater. 2005, 126, 198-201. [CrossRef]

46. Ncibik, M.C. Applicability of some statistical tools to predict optimum adsorption isotherm after linear and non-linear regression analysis. J. Hazard. Mater. 2008, 153, 207-212. [CrossRef]

47. Parimal, S.; Prasad, M.; Bhaskar, U. Prediction of Equilibrium Sorption Isotherms: Comparison of Linear and Nonlinear Methods. Ind. Eng. Chem. Res. 2010, 49, 2882-2888. [CrossRef]

48. Osmani, T.A.; Gallon, R.; Schwaab, M.; Barbosa-Coutinho, E.; Severo, J.B., Jr.; Pinto, J.C. Statistical Analysis of Linear and Non-Linear Regression for the Estimation of Adsorption Isotherm Parameters. Adsorpt. Sci. Technol. 2013, 31, 433-458. [CrossRef]

49. Hutson, N.D.; Yang, R.T. Theoretical Basis for the Dubinin-Radushkievitch (D-R) Adsorption Isotherm Equation. Adsorption 1997, 3, 189-197. [CrossRef]

50. Dabrowski, A. Adsorption-From theory to practice. Adv. Colloid Interface Sci. 2001, 93, 135-224. [CrossRef]

51. Meghea, A.; Rehner, H.H.; Peleanu, I.; Mihalache, R. Test-fitting on adsorption isotherms of organic pollutants from waste waters on activated carbon. J. Radioanal. Nuclear Chem. 1998, 229, 105-110. [CrossRef]

52. Krishna, B.S.; Murty, D.S.R.; Prakash, B.S.J. Thermodynamics of chromium (VI) anionic species sorption onto surfactant-modified montmorillonite clay. J. Colloid Interface Sci. 2000, 229, 230-236. [CrossRef]

53. Lin, S.H.; Juang, R.S. Heavy metal removal from water by sorption using surfactant-modified montmorillonite. J. Hazard. Mater. B 2002, 92, 315-326. [CrossRef]

54. Wang, C.C.; Juang, L.C.; Lee, C.K.; Hsua, T.C.; Leeb, J.F.; Chaob, H.P. Effects of exchanged surfactant cations on the pore structure and adsorption characteristics of montmorillonite. J. Colloid Interface Sci. 2004, 280, 27-35. [CrossRef] 
55. Alipour, D.; Keshtkar, A.R.; Moosavian, M.A. Adsorption of thorium (IV) from simulated radioactive solutions using a novel electrospun $\mathrm{PVA} / \mathrm{TiO}_{2} / \mathrm{ZnO}$ nanofiber adsorbent functionalized with mercapto groups: Study in single and multi-component systems. Appl. Surf. Sci. 2016, 306, 19-29. [CrossRef]

56. Essomba, J.S.; Ndi Nsami, J.; Belibi Belibi, P.D.; Tagne, G.M.; Ketcha Mbadcam, J. Adsorption of Cadmium (II) Ions from Aqueous Solution onto Kaolinite and Metakaolinite. Pure Appl. Chem. Sci. 2014, 2, 11-30. [CrossRef]

57. Chen, C.; Liu, H.; Chen, T.; Chen, D.; Frost, R.L. An insight into the removal of Pb(II), Cu(II), Cd(II), Zn(II), $\mathrm{Ag}(\mathrm{I}), \mathrm{Hg}(\mathrm{I}), \mathrm{Cr}(\mathrm{VI})$ by $\mathrm{Na}(\mathrm{I})$-montmorillonite and $\mathrm{Ca}(\mathrm{II})$-montmorillonite. Appl. Clay Sci. 2015, 118, $239-247$. [CrossRef]

58. Hu, Q.; Zhang, Z. Application of Dubinin-Radushkevich isotherm model at the solid/solution interface: A theoretical analysis. J. Mol. Liq. 2019, 277, 646-648. [CrossRef]

59. Erdem, E.; Karapinar, N.; Donat, R. The removal of heavy metals by natural zeolites. J. Colloid Interface Sci. 2004, 280, 309-314. [CrossRef]

60. Apiratikul, R.; Pavasant, P. Sorption of $\mathrm{Cu}^{2+}, \mathrm{Cd}^{2+}$ and $\mathrm{Pb}^{2+}$ using modified zeolite from coal fly ash. Chem. Eng. J. 2008, 144, 245-258. [CrossRef]

61. Kralik, M. Adsorption, chemisorption, and catalysis. Chem. Pap. 2014, 68, 1625-1638. [CrossRef]

62. Abollino, O.; Giacomino, A.; Malandrino, M.; Mentasti, E. Interaction of metal ions with montmorillonite and vermiculite. Appl. Clay Sci. 2008, 38, 227-238. [CrossRef]

63. Zhu, C.; Dong, X.; Chen, Z.; Naidu, R. Adsorption of aqueous $\mathrm{Pb}(\mathrm{VI}), \mathrm{Cu}(\mathrm{II}), \mathrm{Zn}(\mathrm{II})$ ions by amorphous tin (VI) phosphate: An excellent inorganic sorbent. Int. J. Environ. Sci. Technol. 2016, 13, 1257-1268. [CrossRef]

64. Baker, H.M. A study of thye binding strength and thermodynamics aspects of cadmiu and lead ions with natural silicate minerals in aqueous solutions. Desalination 2009, 242, 115-127. [CrossRef]

65. Baker, H.M.; Massadeh, A.M.; Younes, H.A. Natural Jordanian zeolite: Removal of heavy metal ions from water samples using column and batch methods. Environ. Monit. Assess. 2009, 157, 319-330. [CrossRef]

66. Alvarez-ayuso, E.; Garcia-Sanchez, A.; Queval, X. Purification of metal electroplating waste waters using zeolites. Water Res. 2003, 37, 4858-4862. [CrossRef]

67. Rao, G.P.C.; Satyaveni, S.; Ramesh, A.; Seshaiah, K.; Murthy, K.S.N.; Choudary, N.V. Sorption of cadmium and zinc from aqueous solutions by zeolite $4 \mathrm{~A}$, zeolite $13 \mathrm{X}$ and bentonite. J. Environ. Manag. 2006, 81, 265-272. [CrossRef]

68. Tseng, R.-L.; Wu, F.-C. Inferring the favorable adsorption level and the concurrent multi-stage process with the Freundlich constant. J. Hazard. Mater. 2008, 155, 277-287. [CrossRef]

69. De Gisi, S.; Giusy, L.; Grassi, M.; Notarnicola, M. Characteristics and adsorption capacities of low-cost sorbents for wastewater treatment: A review. Sustain. Mater. Technol. 2016, 9, 10-40. [CrossRef]

70. Du, T.; Zhou, L.-F.; Zhang, Q.; Liu, L.-Y.; Li, G.; Luo, W.-B.; Liu, H.-K. Mesoporous structured aluminosilicate with excellent adsorption performances for water purification. Sustain. Mater. Technol. 2018, 17, e00080. [CrossRef]

71. Kumari, P.; Alam, M.; Siddiqi, W.A. Usage of nanoparticles as adsorbents for waste water treatment: An emerging trend. Sustain. Mater. Technol. 2019, 22, e00128. [CrossRef]

(C) 2020 by the authors. Licensee MDPI, Basel, Switzerland. This article is an open access article distributed under the terms and conditions of the Creative Commons Attribution (CC BY) license (http://creativecommons.org/licenses/by/4.0/). 